The following is a preprint of:

Justin C Tiano, Rob Witbaard, Magda J N Bergman, Pieter van Rijswijk, Anton Tramper, Dick van Oevelen, Karline Soetaert (2019) Acute impacts of bottom trawl gears on benthic metabolism and nutrient cycling. ICES Journal of Marine Science, fsz060.

The published version can be found at: https://doi.org/10.1093/icesjms/fsz060 


\section{Acute impacts of bottom trawl gears on benthic metabolism and}

\section{2 nutrient cycling}

3 Justin C. Tiano ${ }^{1,3^{*}}$, Rob Witbaard ${ }^{1}$, Magda J.N. Bergman, ${ }^{2}$, Pieter van Rijswijk ${ }^{1}$, Anton Tramper ${ }^{1}$,

4 Dick van Oevelen ${ }^{1}$, Karline Soetaert ${ }^{1,3}$

5

6

7

${ }^{1}$ Royal Netherlands Institute for Sea Research and Utrecht University, Department of Estuarine and Delta Systems, Korringaweg 7, 4401 NT Yerseke, The Netherlands

${ }^{2}$ Royal Netherlands Institute for Sea Research, Department of Ocean Systems, Landsdiep 4, 1797 SZ 't Horntje (Texel), The Netherlands

${ }^{3}$ Ghent University, Department of Biology, Marine Biology Section, Krijgslaan 281/S8, 9000 Ghent, Belgium

*Contact author: Justin.Tiano@ nioz.nl

\section{Abstract}

Research on the environmental impacts of bottom fishing gears has focused mainly on benthic fauna and the physical characteristics of the seafloor. This study assesses the benthic biogeochemical consequences associated with tickler chain beam trawl and electric PulseWing trawl gears. In June 2017, professional fishermen trawled experimental transects with both types of gears in the Frisian Front area of the North Sea. Box core sediment samples and in-situ landers were used to evaluate biogeochemical fluxes and sediment characteristics in untrawled and trawled areas (samples taken 3.5 $-70 \mathrm{~h}$ after fishing). A reduction of sedimentary chlorophyll $a$ was observed, which was larger following tickler chain (83\%) compared to PulseWing trawling (43\%). This displacement of surface material caused significant decreases in the sediment oxygen consumption in tickler chain (41\%) and PulseWing trawled samples (33\%) along with a deeper penetration of oxygen in the sediment (tickler chain: $3.78 \mathrm{~mm}$, PulseWing: $3.17 \mathrm{~mm})$ compared to untrawled areas $(2.27 \mathrm{~mm})$. Our research implies 
that bottom trawl disturbance can lead to immediate declines in benthic community metabolism with tickler chain trawling exhibiting greater and less variable alterations than PulseWing trawling on benthic biogeochemical processes.

Keywords: biogeochemistry, ecosystem functioning, oxygen dynamics, nutrients, beam trawling, pulse trawling, organic carbon, Frisian Front

\section{Introduction}

Concerns over the ecological impacts of bottom trawl fishing have dated back since its inception in the $14^{\text {th }}$ century (Collins, 1887). This form of fishing has since gained widespread use and we find ourselves asking the same questions about its environmental effects as during its commencement.

Current worldwide criticism of bottom trawling and the introduction of the experimental method of "electric pulse fishing" in the North Sea once again brings this topic to the limelight. While we have knowledge of the mechanical (Depestele et al., 2016; Eigaard et al., 2016; O’Neil and Ivanovic, 2016) and ecological (Bergman and van Santbrink, 2000; Kaiser et al., 2006; Hiddink et al., 2017; Sciberras et al., 2018) impacts of bottom trawling on the marine ecosystems, only limited information is available on its effects on benthic biogeochemistry (Kaiser et al., 2002). Furthermore, no research has been conducted on the potential side-effects of electric pulse trawling on geochemical fluxes or benthic ecosystem functioning (Soetaert et al., 2015).

Traditional beam trawls are rigged with tickler chains or chain matrices and scrape the seabed in order to mechanically stimulate and catch flatfish. This can lead to a direct release of nutrients from the sediments which can enhance primary production in the water column (Duplisea et al., 2001; Dounas et al., 2006; Dounas et al., 2007; Couceiro et al., 2013) and may also release contaminated material if present (Bradshaw et al., 2012). Benthic trawling has been linked to reduced oxygen concentrations in the water column (Riemann and Hoffman, 1991), the homogenisation of benthic nutrient profiles (van 
de Velde et al., 2018) and alterations of the sediment redox layer (Depestele et al., 2018). The potential for towed gears to remove and kill benthic fauna (Bergman and Hup, 1992; Bergman and van Santbrink, 2000) can indirectly alter habitat dynamics with the loss of important bioturbators and/or ecosystem engineers (Duplisea et al., 2001; Olsgard et al., 2008). Bottom trawling, dredging or other types of human disturbance has been linked to both the fining (Trimmer et al., 2005; De Backer et al., 2014) and coarsening of the bottom material (Palanques et al., 2014; Depestele et al., 2018), both of which can induce changes to the whole benthic community (De Backer et al., 2014).

The controversial introduction of pulse trawling changed the behaviour and activity of fisherman in the North Sea (Sys et al., 2016). With this method, tickler chains are being replaced by electrodes to electrically stimulate flatfish out of the sediment. Reduced fuel consumption (up to 50\%) from lower towing speeds/decreased drag through the seafloor (van Marlen et al., 2014), reductions and increased survivorship of discards (van Marlen et al., 2014; Batsleer et al., 2016; Reijden et al., 2017) provided evidence for pulse fishing as an environmentally friendly alternative to traditional tickler chain beam trawling. Its popularity amongst the Dutch fishing fleet (Haasnoot et al., 2016), however, was met with international criticism due to increased competition between fishermen (Sys et al., 2016) and ecological concerns over animal welfare (de Haan et al., 2016; Soetaert et al., 2016a; Soetaert et al., 2016b).

Compared to traditional tickler chain trawl gears, pulse trawls show reduced alterations to seabed bathymetry (Depestele et al., 2016; Depestele et al., 2018). It may be speculated that the reduced mechanical disturbance will also lead to a lower impact on benthic biogeochemistry. Nonetheless, concrete knowledge about the potentially negative side-effects of pulse trawling on characteristics such as sediment community metabolism and benthic pelagic coupling is lacking. Further research in these areas is therefore needed to fully understand the environmental effects of different bottom trawl gears.

Our research investigates the impact of both conventional (tickler chain) beam trawl and electric PulseWing trawl gears on benthic biogeochemistry. Along with the mechanical effects from PulseWing and tickler chain trawling, Depestele et al. (2018) explored changes in biogeochemical 
redox conditions associated with the two methods. Here we build upon this knowledge and present the first study with pulse trawling focusing on benthic metabolism and nutrient cycles. We originally aimed for a full BACI (Before-After-Control-Impact) design to allow the comparison of trawled experimental areas and an untrawled reference area before and after the tickler chain and PulseWing fishing disturbances. Due to unforeseen logistic constraints and a severe summer storm which took place at the end of the campaign, a balanced design using all experimental equipment (i.e. in-situ mooring/landers, box cores) could not be achieved. Our untrawled "control" samples, therefore, come from the experimental trawl areas before the fishing disturbance (T0) as well as one sampling period in an adjacent reference area.

86

\section{Materials and Methods}

\section{Study site}

Experimental fishing and sampling were carried out within a one kilometre radius of $53.6816^{\circ} \mathrm{N}$ and $4.4565^{\circ} \mathrm{E}$ at a water depth of $34 \mathrm{~m}$ in the area of the North Sea known as the Frisian Front (Figure 1).

This area provided a promising location for our study due in part to its high productivity and homogeneity. The Frisian Front is a transitional zone between courser sandy sediments in the Southern Bight to the south and the siltier Oyster Grounds to the north. It exhibits fine muddy sand with an organic carbon percentage between 0.28-1.0 (Upton et al., 1993; Gehlen et al., 1995; Lohse et al., 1995; Slomp et al., 1997; Boon and Duineveld, 1998). These sediments are subject to faunal induced mixing with the presence of burrowing organisms such as Callianassa subterranea and Upogebia deltaura (Rowden et al., 1998; Dewicke et al., 2002). Previous research has shown that the area is biologically diverse and relatively high in benthic biomass (Dauwe et al., 1998; Dewicke et al, 2002; Duineveld and Boon, 2002), biological activity (Duineveld et al., 1990; Duineveld et al., 1991), and chlorophyll $a(\mathrm{Chl} a)$ influx to the sediments (Boon et al., 1998) compared with adjacent North Sea habitats. Moreover, areas with these characteristics (muddy sediment/high biomass) are known to be more vulnerable to trawling activity than sandy dynamic habitats (Duplisea et al., 2001; Kaiser et 
al., 2006; Queirós et al., 2006, Allen and Clarke, 2007; Sciberras et al., 2016). These environmental conditions paired with the extensive historical data on the site made the Frisian Front an ideal location to measure the impact of bottom trawl fishing. Vessel monitoring system (VMS) data was used to estimate the likelihood of bottom trawl disturbance within one year prior to the study using the method shown in van Denderen et al., (2014).

\section{Experimental design}

To experimentally determine the biogeochemical impact of tickler chain and PulseWing trawl gears, commercial trawlers were instructed to fish specified areas in the Frisian Front. Information was collected before and after fishing and at a nearby reference location (Figures 1 and 2). Intact sediment samples were brought on-board to obtain information on $\mathrm{Chl} a$, particle size analysis, organic carbon/nitrogen, oxygen microprofiles, porewater nutrients and oxygen/nutrient fluxes while in-situ data for benthic fluxes and water column parameters was also obtained. We looked at short term effects $(<24 \mathrm{hr})$ and longer-term effects $>24 \mathrm{hr}$ in the case of the tickler chain trawler. A summer storm took place during the afternoon of 6 June, which modified the surface sediment due to storminduced sediment resuspension and mixing. Hence, we decided to discard all samples taken after the storm event (Figure 2).

Two rectangular $80 \mathrm{~m}$ by $1000 \mathrm{~m}$ treatment areas were specified for experimental fishing by either beam trawl ("tickler") or pulse trawl ("pulse") gears. A non-fished reference area was chosen south of the treatment areas (Figure 1). The areas were spaced $400 \mathrm{~m}$ apart and aligned parallel but not directly adjacent to each other in order to minimize interference from resuspended sediment caused from the experimental trawling (Figure 1). To ensure full "coverage" of the seafloor being fished in the treatment areas, both vessels conducted 7 trawl passes in parallel yet slightly overlapping trajectories over the treatment areas. Given the widths and the space between the trawl gears, this led to a fishing intensity of 150 to $200 \%$ within the middle portion of the treatment areas (modelled after the procedures conducted in Bergman and van Santbrink, 2000 and Depestele et al., 2016). 
On the $1^{\text {st }}$ of June $2017(8 \mathrm{~h} 30-10 \mathrm{~h})$ the tickler treatment was carried out by the HD 29 commercial vessel which towed its gear at $\sim 6$ knots. Conventional $12 \mathrm{~m}$ wide beam trawl gears (a shoe located at both ends of the beam) were towed at both sides of the ship, each rigged with 8 tickler chains and 10 net ticklers. Following the experimental fishing, a side-scan sonar was used to observe changes in bathymetry caused from tickler chain trawling.

The pulse treatment was carried out by the UK 227 commercial vessel on the $6^{\text {th }}$ of June 2017 (7h30 10h). This vessel trawled at a speed of $\sim 5$ knots and towed a $12 \mathrm{~m}$ wide "HFK PulseWing" at either side of the boat. With the PulseWing, the traditional beam is replaced with an aero foil shaped 'wing' without shoes at the ends but with one "nose" located in the middle of the front section of the gear. The wing creates lift as it is towed through the water similar to an aeroplane wing. It is designed to skim above the seabed with a standard beam trawl net behind it. To stimulate the flatfish from the seabed the tickler chains are replaced by electrodes which use a pulsed bi-polar current. This type of alternating current is used to minimize the effects of electrolysis which would cause corrosion of the electrodes (H.K. Woolthuis, designer of HFK PulseWing, pers. comm). Each pulse wing gear was rigged with 28 electrodes lined up parallel to the fishing direction ( $0.42 \mathrm{~m}$ apart) and worked with a voltage of $50 \mathrm{~V}$ at the electrodes at 80 pulses per second. More details on the fishing gears and electric parameters used, can be found in van Marlen et al., (2014) and de Haan et al., (2016).

\section{Data collection}

\section{Water column plume dynamics}

To investigate the effect of PulseWing trawling on the water column characteristics, a mooring was deployed (4 to 8 June 2018) $100 \mathrm{~m}$ north of the experimental area. The location of the mooring was chosen based on the predicted direction of the current during the experimental fishing operation. The mooring was equipped with an Aanderaa SeaGuard recorder, suspended at $3.5 \mathrm{~m}$ above the sediment (29 m depth) which featured a turbidity sensor which measured suspended particulate matter (SPM), an oxygen optode and doppler current sensor. The logistic and time constraints mentioned earlier did not allow for the planned deployment of this mooring during tickler chain trawling. 
All sampling equipment was deployed from the R.V. Pelagia. A cylindrical NIOZ box corer with an internal diameter of $30 \mathrm{~cm}$ and a height of $55 \mathrm{~cm}$, collected intact sediment samples up to $40 \mathrm{~cm}$ deep into the seafloor. Tickler samples were taken one hour before fishing (T0, 2 box cores, 4 incubations) and $6 \mathrm{~h}$ (T1, 2 box cores, 4 incubations), $30 \mathrm{~h}$ (tickler T2; 2 box cores/incubations) and $75 \mathrm{~h}$ (tickler T3; 3 box cores/incubations) after trawl disturbance (Figure 2). In the pulse treatment area, samples were taken 3 days before trawling (T0, 3 box cores/incubations) and 3.5 hours after trawling (T1, 4 box cores, 7 incubations). For the "control" variable used to compare with trawled conditions, the T0 samples from tickler and pulse areas were combined with additional data ( 2 box cores/incubations) taken from the reference area on 3 June 2017.

\section{Dry sediment parameters and chlorophyll a}

166 All sediment samples were freeze dried and sieved $(1 \mathrm{~mm})$ prior to analysis. Laser diffraction was 167 used to measure particle size analysis (PSA) parameters with a Malvern Mastersizer 2000 (McCave et al., 1986). Organic carbon (OC), was measured by removing carbonate from the total carbon (TC) concentration (with $0.1 \mathrm{~N} \mathrm{HCl}$ ) and calculating the difference (Nieuwenhuize et al., 1994). TC, OC and total nitrogen $(\mathrm{TN})$ content were determined using an Interscience Flash 2000 organic element analyser. Samples for chl $a$ analysis were collected from the top $1 \mathrm{~cm}$ of sediment from each box core and were immediately placed in a $-80{ }^{\circ} \mathrm{C}$ freezer for storage. Sediment phytopigments were extracted with acetone and measured using HPLC methods (Zapata et al., 2000). Subsamples for carbon/nitrogen $(\mathrm{C} / \mathrm{N})$ and PSA were taken with $3.5 \mathrm{~cm}$ diameter sediment cores and were sliced at $2.5 \mathrm{~cm}$ intervals down to $12.5 \mathrm{~cm}$.

\section{On-board measurements: Benthic profiles and fluxes}

177 From the box cores, "incubation" sediment cores (14 cm diameter) with overlying water were 178 subsampled for oxygen microprofiling and subsequent oxygen consumption/nutrient flux incubations 179 (hereafter referred to as "on-board incubations" to distinguish between in-situ lander incubations). 
stirring mechanism which ensured homogenous concentrations of nutrients and $\mathrm{O}_{2}$ but without resuspending the sediment. All incubations were run in a climate-controlled chamber which maintained a constant temperature of $12^{\circ} \mathrm{C}$ representative of the bottom water.

Clark-type $\mathrm{O}_{2}$ micro-electrodes ( $100 \mu \mathrm{m}$ tip size, Unisense) were used to make oxygen-depth profiles in the cores immediately after collection (Revsbech, 1989). In each incubation core, 3 replicate profiles were taken from different areas of the sediment. For each profile, readings were taken at 100$\mu \mathrm{m}$ intervals, starting approximately $10000 \mu \mathrm{m}(10 \mathrm{~mm})$ above the sediment water interface $(100 \%$ $\mathrm{O}_{2}$ saturation) to the depth in the sediment at which all oxygen was depleted (i.e. the oxygen penetration depth $[\mathrm{OPD}])$. A two point calibration was conducted prior to measurements using $100 \%$ and $0 \%$ oxygen saturated seawater to represent water column and anoxic $\mathrm{O}_{2}$ concentrations respectively.

The incubation cores used for oxygen profiling were subsequently placed in a $12^{\circ} \mathrm{C}$ water bath and sealed for up to $12 \mathrm{~h}$ in order to obtain sediment community oxygen consumption (SCOC) estimations in the dark. The oxygen concentration during the incubation period was measured with optode sensors (FireStingO2, Pyroscience) using a measurement interval of 30 seconds. The cores were opened, reaerated and kept for an additional 24-36 h to take samples for nutrient flux measurements. Ammonium $\left(\mathrm{NH}_{4}{ }^{+}\right)$, nitrogen oxides $\left(\mathrm{NO}_{\mathrm{x}}\right)$, phosphate $\left(\mathrm{PO}_{4}{ }^{3-}\right)$ and silicate $\left(\mathrm{SiO}_{2}\right)$ fluxes $\left(\mathrm{mmol} \mathrm{m}^{-2} \mathrm{~d}^{-1}\right)$ were determined by fitting a linear regression over the concentration change in the overlying water over time and multiplying the regression coefficient with the height of the water column. For this regression, water samples were taken at $0,8,16,22,36$, and 48 hours after the start of the incubation with a syringe and filtered $(0.45 \mu \mathrm{m})$ into a $10 \mathrm{~mL}$ polystyrene vial for nutrient analysis $\left(\mathrm{NH}_{4}{ }^{+}, \mathrm{NO}_{\mathrm{x}}\right.$, $\mathrm{PO}_{4}{ }^{3-}$ and $\left.\mathrm{SiO}_{2}\right)$ and stored frozen $\left(-20^{\circ} \mathrm{C}\right)$. Upon thawing, samples were analysed by a SEAL QuAAtro segmented flow analyser (Jodo et al., 1992; Aminot et al., 2009). If the fitted regression was not statistically significant (Pearson correlation, $\mathrm{p}>0.05$ ), it was interpreted as a zero flux.

Box cores were further subsampled for porewater nutrients using $10 \mathrm{~cm}$ diameter sub-cores with vertical sampling ports. These were used in combination with rhizon samplers (Rhizosphere Research Products) to collect water samples at 0,1,2,3,5, 7, and $10 \mathrm{~cm}$ depth (Seeberg-Elverfeldt et al., 2005; 
Dickens et al., 2007; Shotbolt, 2010). Porewater nutrients were stored and analysed using the same methods as the incubation water samples.

\section{In-situ SCOC and nutrient fluxes}

Two ALBEX landers (Autonomous Landers for Biological Experiments) Duineveld et al., 2004; Witbaard et al., 2000) were used to obtain in-situ rates of oxygen and nutrient fluxes from the sediment. The landers were deployed in tickler (1 June 2017) and pulse (6 June 2017) trawled areas within $3 \mathrm{~h}$ after fishing concluded. The exact position inside the tickler trawled area was verified by using a side scan sonar (Kongsberg PULSAR) which was used in conjunction with the Kongsberg EM302m MBES (Multibeam Echosounder) mounted on the RV Pelagia (Figure 3). To gather information from an untrawled location, the landers were positioned inside the pulse treatment area on 4 June 2017 before fishing as the control deployment.

Each lander held 3 measurement chambers enclosing a surface area of $144 \mathrm{~cm}^{2}$. For deployment, the landers were carefully lowered on a cable until they reached the seafloor. After descent, each measurement chamber was autonomously driven into the sediment by a hydraulic mechanism. The insitu incubations lasted $5 \mathrm{~h}$ and began shortly after deployment.

The decrease in oxygen concentration in the headspace of each chamber was measured every 30 seconds using JFE-ALEC rinko optodes. Water in the chamber was stirred with a magnetic stirrer mounted to the lid. At pre-set time intervals, a $30 \mathrm{ml}$ water sample was taken from the headspace of each chamber. At the first (and last) sampling moment, a simultaneous sample from the outside water was taken. In this way a sequence of water samples were taken. Upon retrieval, water samples were immediately frozen and analysed similar to the other nutrient samples. At the end of the incubation, a sliding lid closed the underside of the measurement chamber and the entire sample including the incubated sediment was brought back on board with the lander.

\section{Data analysis and statistics}

Shapiro-Wilk and Levene's tests were conducted to determine if data was normally distributed and/or displayed homogeneity of variances. If assumptions for parametric testing were violated, data was 
normalised using a log-transformation. Differences in depth, biogeochemical parameters (benthic $\mathrm{O}_{2}$ and nutrient fluxes, $\mathrm{OPD}, \mathrm{Chl} a$, porewater nutrients, $\mathrm{OC}, \mathrm{TN}$ ), and sediment characteristics (\% silt, \% fine sand, D50, D10) between T0 samples from the tickler chain, PulseWing and reference areas (i.e. untrawled areas) were tested for by applying a one-way analysis of variance (ANOVA). A one-way ANOVA was used to investigate significant differences in biogeochemical and sediment parameters between tickler T1, tickler T2, tickler T3, pulse T1 and untrawled samples. If significant differences were detected by the ANOVA, a Tukey HSD post hoc test was applied to perform pairwise comparisons between specific treatments. To quantify the relationship between water column oxygen and SPM concentrations, a linear regression was performed. All statistical analyses were performed using R (R Core Team, 2013).

\section{Results}

\section{Study site characteristics}

Data from the echosounder showed no significant differences in depth between sample locations in tickler, pulse, or reference areas (ANOVA, $\mathrm{p}>0.05$ ). Additionally, untrawled sediment from tickler $\mathrm{T}$, pulse $\mathrm{T} 0$ and reference box core samples did not show significant differences between $\mathrm{O}_{2} /$ nutrient fluxes, porewater nutrients, chl $a, \mathrm{OC}, \mathrm{TN}$, measurements or grain size characteristics (ANOVA, $\mathrm{p}$ > 0.05). Therefore, for the rest of the analyses, data from the T0 (pulse and tickler) and reference samples were pooled to act as the control treatment representing the untrawled situation. Estimates of trawl disturbance using VMS data suggested that in the year leading up to the study, the fishing effort within the treatment areas was minimal with little to no beam trawling occurring, however, the analysis also suggested a possibility $(0.25-1.25 \mathrm{~h}$ fished) of pulse trawling conducted in part of the reference area.

Our personal observations confirmed that both tickler chain and PulseWing commercial trawlers made 7 trawl passes through the designated treatment areas. The effect of tickler chain trawling was also verified by using side-scan sonar, which showed the mechanically disturbed seabed across the 
planned treatment area (Figure 3). Furthermore, the sonar images revealed that the benthic landers were placed inside the disturbed area (Figure 3). Unfavourable weather conditions prevented us from using the side scan sonar following PulseWing trawling. As a result, we relied on the visual tracking of the pulse trawler using its AIS (Automatic Identification System) from the RV Pelagia.

\section{Effect of the PulseWing on sediment plume dynamics}

The turbidity sensor on the mooring logged a notable increase in the suspended particulate matter (SPM) concentration, including distinct peaks with each passage of the PulseWing trawl (Figure 4). SPM concentrations ranged from 4.0 to $23.2 \mathrm{mg} \mathrm{L}^{-1}$ and increased rapidly whenever the pulse trawler passed through its designated treatment area. The peaks in SPM coincided with dips in the dissolved oxygen concentration (Figure 4a). Linear regression analysis showed that $73 \%$ of the variation in oxygen concentration was accounted for by the variations in turbidity during experimental pulse fishing demonstrating an inverse relationship ( $<<0.001$; Figure $4 b)$. Data from the SeaGuard showed that at the time of trawling, the current was northward and in the direction of the mooring and with a current velocity between 3 and $15 \mathrm{~cm} / \mathrm{s}$.

\section{Fishing effects on sediment characteristics}

\section{Physical sediment parameters}

Box core sediment samples collected after beam trawling (tickler T1, tickler T2) exhibited a fluffy layer of fine sand at the surface which was not present in control samples. Tickler samples also appeared visibly "flatter" in topography, while control samples displayed superficial sand ripples. These characteristics (finer sediment layer/flat topography) were present in some but not all sediment samples taken after pulse trawling (pulse T1).

Deeper sediment layers $(2.5-12.5 \mathrm{~cm})$ did not exhibit any significant differences for physical sediment characteristics between treatments or surface sediment (ANOVA, $p>0.05$ ). The following, therefore only documents the changes found in the upper sediment layers $(0-2.5 \mathrm{~cm})$. Table 1 shows results from the grain size measurements in control, tickler chain, and PulseWing trawled box core samples. Smaller mean silt $(<63 \mu \mathrm{m})$ fractions were found for tickler T1 and tickler T2 compared to 
control and pulse $\mathrm{T} 1$ and tickler $\mathrm{T} 3$ samples (Table 1). This was significant for tickler T2 versus control (HSD, p < 0.001), pulse T1 (HSD, p < 0.01), and tickler T3 (HSD, p < 0.001) sediments. Fine sand $(62.5-125 \mu \mathrm{m})$ fractions in tickler T2 were significantly higher than control (HSD, $\mathrm{p}<0.05)$, pulse T1 (HSD, $\mathrm{p}<0.05$ ), and tickler T3 (HSD, $\mathrm{p}<0.05)$ samples while fine sand fractions in tickler T1 were significantly higher compared to only the pulse T1 sediments (HSD, $p<0.05)$. For D10 values (10\% of the sample particles are smaller than this value), tickler T1 and tickler T2 were significantly higher than control (HSD, $\mathrm{p}<0.05, \mathrm{p}<0.0001$ ), pulse T1 (HSD, $\mathrm{p}<0.001, \mathrm{p}<0.0001$ ), and tickler T3 (HSD, $\mathrm{p}<0.001, \mathrm{p}<0.0001)$ samples showing coarsening after beam trawl fishing (tickler T1/T2), followed by the reestablishment of ambient sediment characteristics (tickler T3). For all grain size measurements, control, tickler T3 and pulse T1 samples displayed similar values which were not statistically different from each other (ANOVA, $p>0.05$; Table 1).

Table 2 documents organic carbon and total nitrogen in surface sediments $(0-2.5 \mathrm{~cm})$. OC and TN displayed similar patterns to the silt content. Average organic carbon in surface sediments was highest in pulse T1 samples but was only significantly higher than tickler T2 (HSD, $p<0.05$; Table 2). Total nitrogen content in these sediments was significantly lower in tickler T2 samples compared with control (HSD, $\mathrm{p}<0.05)$ and pulse T1 (HSD, $\mathrm{p}<0.01)$ values (Table 2).

\section{Chlorophyll-a in surface sediments}

Figure 5 illustrates the relationship between average levels of surface chlorophyll $a$ amongst control, tickler T1 and pulse T1 treatments. Control samples had an average chl $a$ concentration of $3.01 \pm 0.68$ $\mu \mathrm{g} \operatorname{chl} a \mathrm{~g}^{-1}$, while fished samples decreased to $0.51 \pm 0.17 \mu \mathrm{g}$ chl $a \mathrm{~g}^{-1}$ for tickler T1 and $1.76 \pm 0.91$ $\mu \mathrm{g} \operatorname{chl} a \mathrm{~g}^{-1}$ for pulse T1. The acute impact from both fishing methods caused a significant decrease in surface chl $a$ compared with the control areas, however, the effect of the tickler chain trawl (tickler T1; HSD, $\mathrm{p}<0.0001$ ) was more pronounced and less variable than the effects of the PulseWing trawl (pulse T1; HSD, p < 0.05; Figure 5). Surface chl $a$ in tickler T2 samples remained significantly lower than in control samples $\left(0.71 \pm 0.29 \mu \mathrm{g}\right.$ chl $\left.a \mathrm{~g}^{-1}, \mathrm{HSD}, \mathrm{p}<0.001\right)$. Compared to tickler T2, tickler T3 samples showed an increase (though not significantly different than T1 or T2) in chl $a$ at $1.50 \pm 0.61$ $\mu \mathrm{g} \operatorname{chl} a \mathrm{~g}^{-1}$, though this was still significantly lower than control samples (HSD, $\left.\mathrm{p}<0.05\right)$. 


\section{Fishing effects on oxygen and nutrients}

Porewater $\mathrm{NH}_{4}{ }^{+}$profiles in control samples exhibited a depth gradient with $<15 \mu \mathrm{mol}$ at the surface that steadily increased down to $40 \mu \mathrm{mol}$ at $10 \mathrm{~cm}$ depth (Figure 6). Following tickler and pulse trawling, average $\mathrm{NH}_{4}{ }^{+}$concentrations in the upper $3 \mathrm{~cm}$ of the box cores were significantly elevated for tickler T1 (HSD, p < 0.01) and pulse T1 (HSD, p < 0.05) treatments compared with control samples (Table 3). Tickler T1 samples in particular, had a more homogenous depth profile of $\mathrm{NH}_{4}^{+}$ compared with the control samples (Figure 6a). $\mathrm{NH}_{4}{ }^{+}$found in the top $3 \mathrm{~cm}$ of the tickler T2 samples remained higher than the control sediments, albeit not significantly (Table 3). Control samples in the upper $3 \mathrm{~cm}$ exhibited the highest average concentrations of porewater $\mathrm{NO}_{\mathrm{x}}$ and $\mathrm{SiO}_{2}$ as well as the lowest values for $\mathrm{PO}_{4}{ }^{3-}$ compared to trawled (tickler T1, tickler T2, pulse T1) samples, though the differences were not statistically significant (Table 3). Deeper $(5-10 \mathrm{~cm})$ sediment layers showed no significant patterns between porewater nutrients in control, tickler or pulse samples (ANOVA, p > 0.05). No porewater samples were collected for Tickler T3.

The average oxygen penetration depth after tickler chain trawling (tickler T1) was $3776 \pm 731 \mu \mathrm{m}$. In comparison, pulse T1 cores had an oxygen penetration depth of $3166 \pm 1808 \mu \mathrm{m}$. These were both deeper than the OPD's found in the control cores which measured $2250 \pm 565 \mu \mathrm{m}$ though the difference was only significant between the control and tickler T1 treatments (HSD, $p<0.001$; Figure 7). Accurate OPD measurements for tickler T2 could not be obtained, because of variability created from macrofaunal burrows near the sediment water interface. However, the OPD in tickler T3 samples were not significantly deeper than control profiles $(2972 \mu \mathrm{m} \pm 935 ; \mathrm{HSD}, \mathrm{p}<0.05)$.

Table 4 shows the average $\mathrm{O}_{2}$ and nutrient flux values between on-board and in-situ incubations (note: $\mathrm{O}_{2}$ "fluxes" in the table are denoted as negative to be consistent with the nutrient flux data, while intext $\mathrm{O}_{2}$ "consumption" data are positive by definition). Sediment community oxygen consumption (SCOC) was significantly higher in the control incubations compared to both tickler T1 (HSD, p < 0.001) and pulse T1 (HSD, p < 0.05) treatments (Table 4, Figure 8). SCOC in tickler T2 and T3 samples remained significantly lower than the control (HSD, p < 0.05) measurements (Table 4). In- 
situ oxygen consumption measured by the ALBEX landers was lowest after tickler chain trawling, and highest after PulseWing trawling though the differences were not significant (Figure 8b, Table 4).

Nutrient fluxes from the on-board incubation cores showed no significant differences between fished or control treatments (ANOVA, $\mathrm{p}>0.05$, Table 4). Phosphate fluxes from on-board incubations were close to zero with the highest flux coming from Pulse T1 samples $\left(0.002 \pm 0.02 \mathrm{mmol} \mathrm{m}^{2} \mathrm{~d}^{-1}\right)$ and the lowest showing an influx from the control sediments $\left(-0.003 \pm 0.02 \mathrm{mmol} \mathrm{m}^{2} \mathrm{~d}^{-1}\right) \cdot \mathrm{NH}_{4}{ }^{+}$fluxes ranged from $0.35 \pm 0.41 \mathrm{mmol} \mathrm{m}^{2} \mathrm{~d}^{-1}$ at tickler $\mathrm{T} 1$ to $0.10 \pm 0.25 \mathrm{mmol} \mathrm{m}^{2} \mathrm{~d}^{-1}$ in tickler T2 samples.

In-situ incubations yielded lower $\mathrm{NO}_{\mathrm{x}}$ fluxes after tickler chain and PulseWing trawling compared to the control deployment which was statistically significant for the tickler treatment $(\mathrm{HSD}, \mathrm{p}<0.05)$. No other significant differences were found in nutrient fluxes between control, tickler or pulse lander deployments, however, in-situ estimates for $\mathrm{PO}_{4}{ }^{3-}$ and $\mathrm{SiO}_{2}$ fluxes were markedly higher than in the on-board incubations (Table 4). It is noted that data from only one of the landers could be used after PulseWing trawling. Storm induced water currents created a build-up of sediment which partially buried the incubation chambers of one of the landers (which was evidenced upon retrieval) and seemed to create irregular measurements. Data was, therefore, used only from the lander which showed a range of flux data comparable to historical information from the Frisian Front.

\section{Discussion}

In this study we compared the effects of conventional tickler chain trawling and electric pulse fishing on benthic biogeochemical functioning and water column processes in the Frisian Front, an area located $50 \mathrm{~km}$ off the Dutch Coast characterised by fine sandy sediments. Despite unfortunate methodological constraints, we were able to effectively capture and assess the acute effects of bottom trawl activity on the biogeochemical functioning of North Sea sediments. In particular, our results show that trawling resulted in clear differences between chl $a$ (labile organic material), and oxygen dynamics in trawled and untrawled sediments. Here, we discuss the effect of bottom fishing on water 
column properties, followed by sedimentary organic and inorganic solid particles, to end with the impact on benthic oxygen and nutrient dynamics.

\section{Effects in the water column}

The mooring, deployed during PulseWing trawling, showed increased turbidity after each pass of the fishing vessel (Figure 4), indicating resuspension of sediments to the overlying water. This data supports the findings of Depestele et al., (2016) who recorded sediment resuspension from both tickler chain and pulse trawled gears. Concurrent with the increased turbidity, we observed prominent drops in water column oxygen concentrations (Figure 4a). A similar decrease in water column $\mathrm{O}_{2}$ was documented by Riemann and Hoffman, (1991) after mussel dredging in the Limfjord. The release of low oxygenated porewater and reoxidation of reduced substances resuspended from the sediment may be the primary cause for the increased water column $\mathrm{O}_{2}$ uptake (Almroth et al., 2009; Almroth-Rosell et al., 2012).

The sediment data are consistent with these water column observations. The decrease of silt, chlorophyll and organic carbon in the upper sediment layers after fishing suggests resuspension of these substances to the water column. Furthermore, the reduction in sediment oxygen uptake that we found after fishing suggests that part of the metabolic activity, due to removal of labile organic matter and loss of reduced compounds, is displaced from the sediment to the overlying water.

\section{Removal of surficial sediment}

We observed an overall coarsening in surface sediments due to trawl activity (Table 1), which is in agreement with Depestele et al., (2018), Mengual et al., (2016) and Palanques et al., (2014). The appearance of finer particles on the sediment surface after tickler chain trawling, however, suggests that two processes are occurring: 1) the smallest sediment fraction (silt) is winnowed and reallocated away from the trawl track, while 2) the heavier sand fractions resettled or remained on the trawl track leaving finer particles (but not the finest silt fraction) sorted on the surface with heavier particles underneath. As sedimentary organic carbon and nitrogen are strongly associated to the abundance of fine sediment, the winnowing of the upper silt fraction led to decreases in OC, TN as well as chl $a$. 
Tickler T3 samples showed reintegration of silt particles in the upper sediment layers along with OC and TN (Tables 1 and 2). This relatively fast "recovery" of sediment parameters may have occurred through bioturbation activity as infaunal organisms such as Upogebia deltaura and Callianassa subterranea rebuild their burrows after disturbance and are known to expel large amounts of sediments from depth (Rowden et al., 1998).

Our study was conducted after the spring bloom (April/May), which provides an annual influx of chl $a$ from the water column onto the sediment surface of the Frisian Front (Boon and Duineveld, 1996; Boon and Duineveld, 1998). Both trawl types induced large reductions of sediment $\operatorname{chl} a$ (83\% tickler T1, 45\% - pulse T1; Figure 4), implying that trawling physically removed the top sediment layer along with the labile organic material within it, lowering benthic food quality (Watling et al., 2001). The observed reductions in sedimentary OC and chl $a$ are in agreement with Brylinsky et al, (1994) and Watling et al., (2001), who documented significant losses of phytopigments shortly after towing bottom trawl gears in shallow ( $<15 \mathrm{~m}$ ) sediments. The loss of chl $a$ is expected if an acute mechanical stressor, such as bottom trawling, is able to displace the surface sediment, however, longer-term effects on sediment phytopigments and organic material may vary.

Pusceddu et al., (2014) sampled chronically trawled versus untrawled deep sea (500 - $2000 \mathrm{~m}$ ) sediments and reported reduced chl $a$ and OC concentrations due to bottom trawling. In shallower (10 - 70 m) environments Pusceddu et al., (2005) and Palanques et al., (2014), however, associated increased OC with greater annual trawl intensities. Sciberras et al., (2016) related higher chl $a$ with long-term trawl disturbance. In the Bay of Fundy, Brylinsky et al, (1994) detected an increase in sediment chl $a$ occurring 80 days after an initial depletion of phytopigments caused from experimental trawling. Enhanced OC and chl $a$ production after bottom trawl disturbance may come as a delayed response due to the loss of microbial (Watling et al., 2001) or macrofaunal (Bergman and Hup, 1992; Bergman and van Santbrink, 2000; Tanner, 2003) biomass leading to reduced grazing activity and/or the eventual settling of silt particles (Palanques et al., 2014). Watling et al., (2001) saw an 88\% decline in surface chl $a$ immediately after scallop dredging in shallow $(15 \mathrm{~m})$ water but reported only a 4\% difference in chl $a$ from disturbed and adjacent areas four months after the fishing. Deep sea 
environments lack the biological and physical mechanisms to recover quickly from disturbance, thus

418 leaving OC and pigment levels in their depleted state for longer periods of time.

\section{Effect on biogeochemical profiles and fluxes}

420 The significant increase in porewater $\mathrm{NH}_{4}{ }^{+}$after tickler chain and PulseWing trawling (tickler

$421 \mathrm{~T} 1 /$ pulse T1) in the top $3 \mathrm{~cm}$ sediment suggest a physical disturbance in the upper sediment layer

422 (Table 3, Figure 5). As it can take several months for $\mathrm{NH}_{4}{ }^{+}$to reach a new steady state after sediment disturbance (van de Velde et al., 2018), these altered profiles probably show transient effects, reflecting the removal of the upper sediment layer and/or the homogenisation of the sediment column. Oxygen, in contrast will more quickly reach its steady state in the sediment.

Decreased labile organic material and the removal of reduced compounds will lower SCOC and increase $\mathrm{O}_{2}$ concentrations in the sediment, thereby increasing the OPD (Gundersen and Jorgensen, 1990). Our results demonstrate this pattern as fishing disturbance led to deeper OPD's in addition to the reduction in SCOC (Figures 7 and 8) and chl $a$ (Figure 5). The OPD's in our study were $40 \%$ deeper in the tickler T1 and 29\% deeper in pulse profiles in comparison with control samples (Figure 7). These results are supported by Allen and Clarke, (2007)'s prediction of a deeper sediment oxic layer following bottom trawl disturbance.

Sediment community oxygen consumption (SCOC) can be used as a measure for total (oxic and anoxic) sediment metabolism, as it represents the collective respiration of microbial, meiofaunal and macrofaunal communities residing in the sediment, as well as chemical reoxidation processes of reduced compounds (Glud 2008). Historical data from the Frisian Front shows seasonal variation in

$437 \mathrm{O}_{2}$ consumption from $5 \mathrm{mmol} \mathrm{O}_{2} \mathrm{~m}^{2} \mathrm{~d}^{-1}$ during winter months to its peak in August at around $50 \mathrm{mmol}$ $\mathrm{O}_{2} \mathrm{~m}^{2} \mathrm{~d}^{-1}$ (van Raaphorst et al., 1992; Nedwell, et al., 1993; Upton et al., 1993; Boon et al., 1998; Boon and Duineveld, 1998). From the month of June, $\mathrm{O}_{2}$ consumption ranges between 15 to $36 \mathrm{mmol}$ $\mathrm{O}_{2} \mathrm{~m}^{2} \mathrm{~d}^{-1}$ (Upton et al., 1993; Boon et al., 1998; Boon and Duineveld, 1998), which is comparable with the SCOC rates from our study before trawling. 
442 Although the differences in $\mathrm{O}_{2}$ consumption from the in-situ lander incubations were not statistically

443 significant, the results are complimentary to the data from our on-board incubations, implying that

444 fishing with tickler chains is more likely to cause reductions in SCOC than PulseWing trawling. The reduction of SCOC rates and deepening of the OPD after trawl disturbance is consistent with the removal of the reactive top layer of sediment, as demonstrated by the loss in chlorophyll and organic matter. This top layer typically also holds high abundances of microbial (Watling et al., 2001) and macrofaunal (Dauwe et al., 1998) organisms. Thus, removal of this layer likely decreased the overall biological activity and carbon mineralisation in these sediments.

To our knowledge, we are the first to report significantly decreased SCOC rates and increased $\mathrm{O}_{2}$ penetration in marine sediments following bottom trawling. Trimmer et al., (2005) found no significant changes in oxygen uptake between trawled (various bottom gear types) and untrawled sandy sediments in the southern North Sea. Sciberras et al., (2016) did not find a significant effect of bottomfishing (scallop dredge/otter trawl) on OPD in sandy and muddy sediments in the Irish Sea. In the soft sediments of Galveston Bay Texas, Warnken et al., (2003) found inconsistent results in their oxygen flux measurements leading them to conclude that $\mathrm{O}_{2}$ consumption was not affected by shrimp trawling. Our results contrast with the findings of van de Velde et al., (2018) who reported, a drastic increase in total carbon mineralisation rates after anthropogenic caused mixing in carbon rich muddy sediments off the coast of Belgium. The increase was attributed to the re-exposure of previously buried organic material to oxic conditions. The sediments in their study, however, are extremely eutrophic and therefore not representative for most North Sea sediments. In comparison, Frisian Front sediments are less metabolically active, contain significantly less carbon, and have much higher macrofaunal activity.

464 Nutrient fluxes measured in sediment cores and in-situ were quite variable both in the control and 465 trawled areas. The ammonium fluxes $\left(0.10-0.61 \mathrm{mmol} \mathrm{m}^{2} \mathrm{~d}^{-1}\right)$ were lower than the maximum summertime values recorded in previous studies, but were well within the range of annual fluctuations in $\mathrm{NH}_{4}{ }^{+}$flux (-0.1 $\left.-1.7 \mathrm{mmol} \mathrm{m}^{2} \mathrm{~d}^{-1}\right)$ in this area (van Raaphorst et al., 1992; Nedwell, et al., 1993; 
summer, however, van Raaphorst et al. (1992) found that $\mathrm{NO}_{\mathrm{x}}$ fluxes in June remained closer to 0.1 mmol m $\mathrm{d}^{-1}$ which is comparable to the fluxes found in our study (Table 4). Whereas the $\mathrm{NH}_{4}{ }^{+}$fluxes between treatments in our study were not significantly different, we found a $50 \%$ decrease between in-situ lander $\mathrm{NO}_{\mathrm{x}}$ fluxes from control and tickler trawled incubations. The Frisian Front exhibits distinct porewater $\mathrm{NO}_{\mathrm{x}}$ maxima near the sediment surface (Lohse et al., 1995), which is consistent with the nitrate fluxing out of the sediment (Table 4). The removal of the top sediment layer may have weakened the diffusive gradient between $\mathrm{NO}_{\mathrm{x}}$ and the overlying water, therefore reducing fluxes from the sediment.

In-situ lander flux estimates were consistently higher for oxygen, phosphate and silicate compared with on-board incubations (Table 4). Cores used for the on-board incubations held $22 \mathrm{~cm}$ of sediment at most, and so the fluxes recorded in the on-board incubation cores, measure the results of processes occuring within this space. The in-situ landers have no such limitation and measure fluxes over a deeper sediment layer. Bioturbating infauna in the North Sea are known to contribute to significant releases of silicate from the sediment (Olsgard et al., 2008). A prominent mud shrimp in the Frisian Front, $C$. subterranea, has burrows extending down to $81 \mathrm{~cm}$, and water in its burrows can hold higher concentrations of phosphate and ammonium compared to the overlying water (Witbaard and Duineveld, 1989, Rowden and Jones, 1995). Macrofaunal burrows were frequently seen in our sediment samples, several of which extended beyond the bottom of the incubation cores. We therefore infer that processes occurring deep in the sediment are the primary cause for the discrepancy in fluxes measured in our in-situ landers compared with the on-board incubations, where the former includes the impact of deep dwelling organisms, and the latter does not. Wave-induced advective transport may have also played a role in our in situ lander results if waves were able to pump burrow water into the measurement chambers. The impermeable muddy sand in the Frisian Front, however, would prevent this process from occurring through advective porewater transport.

\section{Implications}


trawling may potentially induce long-term impacts on benthic biogeochemical cycles in certain sediments (Pusceddu et al., 2014; van de Velde et al., 2018). Our study adds the ability for bottom trawl gears to slow down overall benthic metabolism, at a time scale of several days at the least. The lowering of benthic oxygen consumption and the simultaneous increase in oxygen demand from the water column, provides evidence that trawling displaces part of the benthic activity into the overlying water. Given the global scope of bottom trawl fishing, this has widespread implications for carbon mineralization and nutrient cycling. The significant loss of labile organic matter (in the form of chl $a$ ) from the sediments after trawl disturbance and consequent lowering of the food quality may also affect benthic lifeforms on longer time scales.

Finally, this study demonstrated the greater and less variable impact of tickler chain beam trawl gears on biogeochemical functioning when compared with PulseWing trawling. Information gained from this research has implications for bottom trawl fisheries management and provides concrete evidence linking lower mechanical disturbance in fishing gears to a reduced impact on benthic marine ecosystems.

\section{Acknowledgements}

We thank the crews of the fishing vessels HD 29 and UK 227 for their cooperation and participation in this study as well as the crew of the RV Pelagia for providing the means to collect the data for this study. We express our gratitude to the NIOZ analytical lab for processing nutrient and sediment samples and also thank the various $\mathrm{PhD}$ students helping collect samples during this field expedition. Vessel Monitoring System data aiding in the planning and assessment of this research was provided through Wageningen Marine Research and analysed by Niels Hintzen and Karin van der Reijden. The research was made possible by the European Maritime and Fisheries Fund (EMFF) and the Netherlands Ministry of Agriculture Nature and Food Quality (LNV). This article does not necessarily reflect the view of European Commission or the Netherlands Ministries and does not anticipate the Commission/Dutch government's future policy in this area. The authors declare that they have no conflicts of interest (financial or otherwise) regarding this research. 
522

523

524

525

526

527

528

529

530

531

532

533

534

535

536

537

538

539

540

541

542

543

544

545

546

\section{Literature Cited}

Allen, J. I., and Clarke, K. R. 2007. Effects of demersal trawling on ecosystem functioning in the North Sea: A modelling study. Marine Ecology Progress Series, 336: 63-75.

Almroth-Rosell, E., Tengberg, A., Andersson, S., Apler, A., and Hall, P. O. J. 2012. Effects of simulated natural and massive resuspension on benthic oxygen, nutrient and dissolved inorganic carbon fluxes in Loch Creran, Scotland. Journal of Sea Research, 72: 38-48.

Almroth, E., Tengberg, A., Andersson, J. H., Pakhomova, S., and Hall, P. O. J. 2009. Effects of resuspension on benthic fluxes of oxygen, nutrients, dissolved inorganic carbon, iron and manganese in the Gulf of Finland, Baltic Sea. Continental Shelf Research, 29(5-6): 807-818.

Batsleer, J., Rijnsdorp, A. D., Hamon, K. G., van Overzee, H. M. J., and Poos, J. J. 2016. Mixed fisheries management: Is the ban on discarding likely to promote more selective and fuel efficient fishing in the Dutch flatfish fishery? Fisheries Research, 174: 118-128.

Bergman, M. J. N., and Hup, M. 1992. Direct effects of beam trawling on macrofauna in a sandy sediment in the southern North Sea. ICES Journal of Marine Science, 49: 5-11.

Bergman, M. J. N., Ubels, S. M., Duineveld, G. C. A., and Meesters, E. W. G. 2015. Effects of a 5year trawling ban on the local benthic community in a wind farm in the Dutch coastal zone. ICES Journal of Marine Science, 72(3): 962-972.

Bergman, M., and van Santbrink, J. W. 2000. Mortality in megafaunal benthic populations caused by trawl fisheries on the Dutch continental shelf in the North Sea in 1994. ICES Journal of Marine Science, 57: 1321-1331.

Boon, A., and Duineveld, G. 1998. Chlorophyll a as a marker for bioturbation and carbon flux in southern and central North Sea sediments. Marine Ecology Progress Series, 162: 33-43.

Boon, A. R., and Duineveld, G. C. A. 1996. Phytopigments and fatty acids as molecular markers for the quality of near-bottom particulate organic matter in the North Sea. Journal of Sea Research, 35(4): 279-291. 
Boon, A. R., Duineveld, G. C. A., Berghuis, E. M., and Van Der Weele, J. A. 1998. Relationships between benthic activity and the annual phytopigment cycle in near-bottom water and sediments in the southern North Sea. Estuarine, Coastal and Shelf Science, 46(1): 1-13.

Bradshaw, C., Tjensvoll, I., Sköld, M., Allan, I. J., Molvaer, J., Magnusson, J., Naes, K., Nilsson, H. C. 2012). Bottom trawling resuspends sediment and releases bioavailable contaminants in a polluted fjord. Environmental Pollution, 170: 232-241.

Brylinsky, M., Gibson, J., and Gordon Jr., D. C. 1994. Impacts of Flounder Trawls on the Intertidal Habitat and Community of the Minas Basin, Bay of Fundy. Canadian Journal of Fisheries and Aquatic Sciences, 51(3): 650-661.

Collins, J. W. 1887. The Beam-trawl Fishery of Great Britain, with notes on beam-trawling in other european countries, etc. Bulletin of the United States Fish Commission, 19: 289-407.

Couceiro, F., Fones, G. R., Thompson, C. E. L., Statham, P. J., Sivyer, D. B., Parker, R., KellyGerreyn, B. A. et al. (2013). Impact of resuspension of cohesive sediments at the Oyster Grounds (North Sea) on nutrient exchange across the sediment-water interface. Biogeochemistry, 113(1-3): 37-52.

Dauwe, B., Herman, P. M. J., and Heip, C. H. R. 1998. Community structure and bioturbation potential of macrofauna at four North Sea stations with contrasting food supply. Marine Ecology Progress Series, 173(1978): 67-83.

De Backer, A., Van Hoey, G., Coates, D., Vanaverbeke, J., and Hostens, K. 2014. Similar diversitydisturbance responses to different physical impacts: Three cases of small-scale biodiversity increase in the Belgian part of the North Sea. Marine Pollution Bulletin, 84(1-2): 251-262.

de Haan, D., , Fosseidengen, J. E., Fjelldal, P. G., Burggraaf, D., and Rijnsdorp, A. D. 2016. Pulse trawl fishing: characteristics of the electrical stimulation and the effect on behaviour and injuries of Atlantic cod (Gadus morhua). ICES Journal of Marine Science, 73: 1557-1569.

Depestele, J., Degrendele, K., Esmaeili, M., Ivanovi, A., Kro, S., Neill, F. G. O., Parker, R. et al. 

2018. Comparison of mechanical disturbance in soft sediments due to tickler-chain SumWing trawl vs . electro-fitted PulseWing trawl. ICES Journal of Marine Science, fsy124: 1-18.

Depestele, J., Ivanovic, A., Degrendele, K., Esmaeili, M., Polet, H., Roche, M., Summerbell, K. et al. 2016. Measuring and assessing the physical impact of beam trawling. ICES Journal of Marine Science, 73: i15-i26.

Dewicke, A., Rottiers, V., Mees, J., and Vincx, M. 2002. Evidence for an enriched hyperbenthic fauna in the Frisian front (North Sea). Journal of Sea Research, 47(2): 121-139.

Dickens, G. R., Koelling, M., Smith, D. C., and Schnieders, L. 2007. Rhizon sampling of pore waters on scientific drilling expeditions: An example from the IODP expedition 302, Arctic Coring Expedition (ACEX). Scientific Drilling, (4): 22-25.

Dounas, C., Davies, I., Triantafyllou, G., Koulouri, P., Petihakis, G., Arvanitidis, C., Sourlatziz, G. 2007. Large-scale impacts of bottom trawling on shelf primary productivity. Continental Shelf Research, 27(17): 2198-2210.

Dounas, C. G. 2006. A new apparatus for the direct measurement of the effects of otter trawling on benthic nutrient releases. Journal of Experimental Marine Biology and Ecology, 339(2): 251259.

Duineveld, G., and Boon, A. 2002. Short-term variations in the fluxes and composition of seston in near-bottom traps in the southern North Sea. Helgoland Marine Research, 56(2): 140-148.

Duineveld, G. C. A., Bergman, M. J. N., and Lavaleye, M. S. S. 2007. Effects of an area closed to fisheries on the composition of the benthic fauna in the southern North Sea. ICES Journal of Marine Science, 64(5): 899-908 .

Duineveld, G. C. A., Lavaleye, M. S. S., and Berghuis, E. M. 2004. Particle flux and food supply to a seamount cold- water coral community (Galicia Bank, NW Spain). Marine Ecology Progress Series, 277: 13-23. 

impacts of bottom trawl fisheries on soft sediment biogeochemistry in the North Sea. Geochemical Transactions, 2: 112.

Eigaard, O. R., Bastardie, F., Breen, M., Dinesen, G. E., Hintzen, N. T., Laffargue, P., Mortensen, L. O. et al. 2016. Estimating seabed pressure from demersal trawls, seines, and dredges based on gear design and dimensions. ICES Journal of Marine Science, 73: i27-i43.

Gundersen, J. K., and Jorgensen, B. B. 1990. Microstructure of diffusive boundary layers and the oxygen uptake of the sea floor. Nature, 345(6276): 604-607.

Haasnoot, T., Kraan, M., and Bush, S. R. 2016. Fishing gear transitions: Lessons from the Dutch flatfish pulse trawl. ICES Journal of Marine Science, 73(4): 1235-1243.

Hiddink, J. G., Jennings, S., Sciberras, M., Szostek, C. L., Hughes, K. M., and Ellis, N. 2017. Global analysis of depletion and recovery of seabed biota after bottom trawling disturbance. Proceedings of the National Academy of Sciences of the United States of America, (114): 83018306.

Jodo, M., Kawamoto, K., Tochimoto, M., and Coverly, S. C. 1992. Determination of nutrients in seawater by analysis rate and reduced interference on segmented-flow analysis with higher ammonia. Journal of Automatic Chemistry, 14(5): 163-167.

Kaiser, M. J., Clarke, K. R., Hinz, H., Austen, M. C. V, Somerfield, P. J., and Karakassis, I. 2006. Global analysis of response and recovery of benthic biota to fishing. Marine Ecology Progres Series, 311: 1-14.

Kaiser, M. J., Collie, J. S., Hall, S. J., Jennings, S., and Poiner, I. R. 2002. Modification of marine habitats by trawling activities: prognosis and solutions. Fish and Fisheries, 3: 114-136.

Lohse, L., Malschaert, J. F. P., Slomp, C. P., Helder, W., and van Raaphorst, W. 1995. Sedimentwater fluxes of inorganic nitrogen compounds along the transport route of organic matter in the North Sea. Ophelia, 41(1): 173-197. 

diffraction-size analyzer for use with natural sediments. Research Methods Papers, (November 1985): 561-564.

Mengual, B., Cayocca, F., Le Hir, P., Draye, R., Laffargue, P., Vincent, B., and Garlan, T. 2016. Influence of bottom trawling on sediment resuspension in the 'Grande-Vasière' area (Bay of Biscay, France). Ocean Dynamics, 66(9): 1181-1207.

Nedwell, D. B., Parkes, R. J., Upton, a. C., and Assinder, D. J. 1993. Seasonal Fluxes across the Sediment-Water Interface, and Processes within Sediments. Philosophical Transactions of the Royal Society A: Mathematical, Physical and Engineering Sciences, 343(1669): 519-529.

Nieuwenhuize, J., Maas, Y. E. M., and Middelburg, J. J. 1994. Rapid analysis of organic carbon and nitrogen in particulate materials. Marine Chemistry, 45: 217-224.

O'Neil, F. G., and Ivanovic, A. 2016. The physical impact of towed demersal fishing gears on soft sediments. ICES Journal of Marine Science, 73: i5-i14.

Olsgard, F., Schaanning, M. T., Widdicombe, S., Kendall, M. A., and Austen, M. C. 2008. Effects of bottom trawling on ecosystem functioning. Journal of Experimental Marine Biology and Ecology, 366(1-2): 123-133.

Palanques, A., Puig, P., Guillén, J., Demestre, M., and Martín, J. 2014. Effects of bottom trawling on the Ebro continental shelf sedimentary system (NW Mediterranean). Continental Shelf Research, 72: 83-98.

Provoost, P., Braeckman, U., Van Gansbeke, D., Moodley, L., Soetaert, K., Middelburg, J. J., and Vanaverbeke, J. 2013. Modelling benthic oxygen consumption and benthic-pelagic coupling at a shallow station in the southern North Sea. Estuarine, Coastal and Shelf Science, 120: 1-11.

Pusceddu, A., Bianchelli, S., Martín, J., Puig, P., Palanques, A., Masqué, P., and Danovaro, R. 2014. Chronic and intensive bottom trawling impairs deep-sea biodiversity and ecosystem functioning. Proceedings of the National Academy of Sciences of the United States of America, 111(24): $8861-8866$. 
Pusceddu, A., Fiordelmondo, C., Polymenakou, P., and Polychronaki, T. 2005. Effects of bottom trawling on the quantity and biochemical composition of organic matter in coastal marine sediments ( Thermaikos Gulf , northwestern Aegean Sea ). Continental Shelf Research, 25: $2491-2505$.

Queirós, A. M., Hiddink, J. G., Kaiser, M. J., and Hinz, H. 2006. Effects of chronic bottom trawling disturbance on benthic biomass, production and size spectra in different habitats. Journal of Experimental Marine Biology and Ecology, 335(1): 91-103.

Revsbech, N. P. 1989. An oxygen microsensor with a guard cathode. Limnology and Oceanography, $34(2), 474-478$.

Riemann, B., and Hoffman, E. 1991. Ecological consequences of dredging and bottom tawling in the Limfjord, Denmark. Marine Ecology Progres Series, 69: 171-178.

Rowden, A. A., Jones, M. B., and Morris, A. W. 1998. The role of Callianassa subterranea (Montagu) (Thalassinidea) in sediment resuspension in the North Sea. Continental Shelf Research, 18(11): $1365-1380$.

Sciberras, M., Hiddink, J. G., Jennings, S., Szostek, C. L., Hughes, K. M., Kneafsey, B., ... Kaiser, M. J. (2018). Response of benthic fauna to experimental bottom fishing: A global meta-analysis. Fish and Fisheries, (February), 1-18.

Sciberras, M., Hiddink, J. G., Jennings, S., Szostek, C., Hughes, K. M., Kneafsey, B., Clarke, L. J. et al. 2018. Response of benthic fauna to experimental bottom fishing: a global meta-analysis. Fish and Fisheries. 1-18

Sciberras, M., Parker, R., Powell, C., Robertson, C., Kro“ger, S., Bolam, S., and Hiddink, J. 2016. Impacts of bottom fishing on the sediment infaunal community and biogeochemistry of cohesive and non-cohesive sediments. Limnology and Oceanography, 61: 2076-2089.

Seeberg-Elverfeldt, J., Schluter, M., Feseker, T., and Kolling, M. 2005. Rhizon sampling of porewaters near the sediment-water interface of aquatic systems. Limnology and Oceanography- 
Methods, 3: 361-371.

Shotbolt, L. 2010. Pore water sampling from lake and estuary sediments using Rhizon samplers. Journal of Paleolimnology, 44(2): 695-700.

Slomp, C. P., Malschaert, J. F. P., Lohse, L., and Van Raaphorst, W. 1997. Iron and manganese cycling in different sedimentary environments on the North Sea continental margin. Continental Shelf Research, 17(9): 1083-1117.

Soetaert, M., Decostere, A., Polet, H., Verschueren, B., and Chiers, K. 2015. Electrotrawling: A promising alternative fishing technique warranting further exploration. Fish and Fisheries, 16(1): $104-124$.

Soetaert, M., Haan, D. De, Verschueren, B., Decostere, A., Puvanendran, V., Saunders, J., Polet, H. 2016. Atlantic Cod Show a Highly Variable Sensitivity to Electric-Induced Spinal Injuries. Marine and Coastal Fisheries, 8(1): 412-424.

Sys, K., Poos, J. J., Meensel, J. Van, Polet, H., and Buysse, J. 2016. Competitive interactions between two fishing fleets in the North Sea. ICES Journal of Marine Science, 73(6): 1485-1491.

Tanner, J. E. 2003. The influence of prawn trawling on sessile benthic assemblages in Gulf St. Vincent, South Australia. Canadian Journal of Fisheries and Aquatic Sciences, 60(5): 517-526.

Trimmer, M., Petersen, J., Sivyer, D. B., Mills, C., Young, E., and Parker, E. R. 2005. Impact of longterm benthic trawl disturbance on sediment sorting and biogeochemistry in the southern North Sea. Marine Ecology Progress Series, 298: 79-94.

Upton, A. C., Nedwell, D. B., Parkes, R. J., and Harvey, S. M. 1993. Seasonal benthic microbial activity in the southern North Sea - Oxygen uptake and sulphate reduction. Marine Ecology Progress Series, 101(3): 273-282.

van Reijden, K. J. Van Der, Molenaar, P., Chen, C., Uhlmann, S. S., Goudswaard, P. C., and Marlen, B. Van. 2017. Survival of undersized plaice ( Pleuronectes platessa ), sole ( Solea solea ), and dab ( Limanda limanda ) in North Sea pulse-trawl fisheries. ICES Journal of Marine Science, 
697

698

699

700

701

702

703

704

705

706

707

708

709

710

711

712

713

714

715

716

717

718

719

fsx019: 1-9.

van de Velde, S., Lancker, V. Van, Hidalgo-martinez, S., and Berelson, W. M. 2018. Anthropogenic disturbance keeps the coastal seafloor biogeochemistry in a transient state. Scientific Reports, (December 2017, 1-10.

van Denderen, P. D., Hintzen, N. T., Rijnsdorp, A. D., Ruardij, P., and van Kooten, T. 2014. HabitatSpecific Effects of Fishing Disturbance on Benthic Species Richness in Marine Soft Sediments. Ecosystems, 17(7): 1216-1226.

Van Marlen, B., Wiegerinck, J. A. M., van Os-Koomen, E., and van Barneveld, E. 2014. Catch comparison of flatfish pulse trawls and a tickler chain beam trawl. Fisheries Research, 151: 5769.

Warnken, K. W., Gill, G. A., Dellapenna, T. M., Lehman, R. D., Harper, D. E., and Allison, M. A. 2003. The effects of shrimp trawling on sediment oxygen consumption and the fluxes of trace metals and nutrients from estuarine sediments. Estuarine, Coastal and Shelf Science, 57(1-2): $25-42$.

Watling, L., Findlay, R. H., Mayer, L. M., and Schick, D. F. 2001. Impact of a scallop drag on the sediment chemistry, microbiota, and faunal assemblages of a shallow subtidal marine benthic community. Journal of Sea Research, 46: 309-324.

Witbaard, R., Duineveld, G. C. A., Weele, J. A. Van Der, Berghuis, E. M., and Reyss, J. P. 2000. The benthic response to the seasonal deposition of phytopigments at the Porcupine Abyssal Plain in the North East Atlantic. Journal of Sea Research, 43: 15-31.

Zapata, M., Rodríguez, F., and Garrido, J. L. 2000. Separation of chlorophylls and carotenoids from marine phytoplankton: A new HPLC method using a reversed phase C8 column and pyridinecontaining mobile phases. Marine Ecology Progress Series, 195: 29-45. 


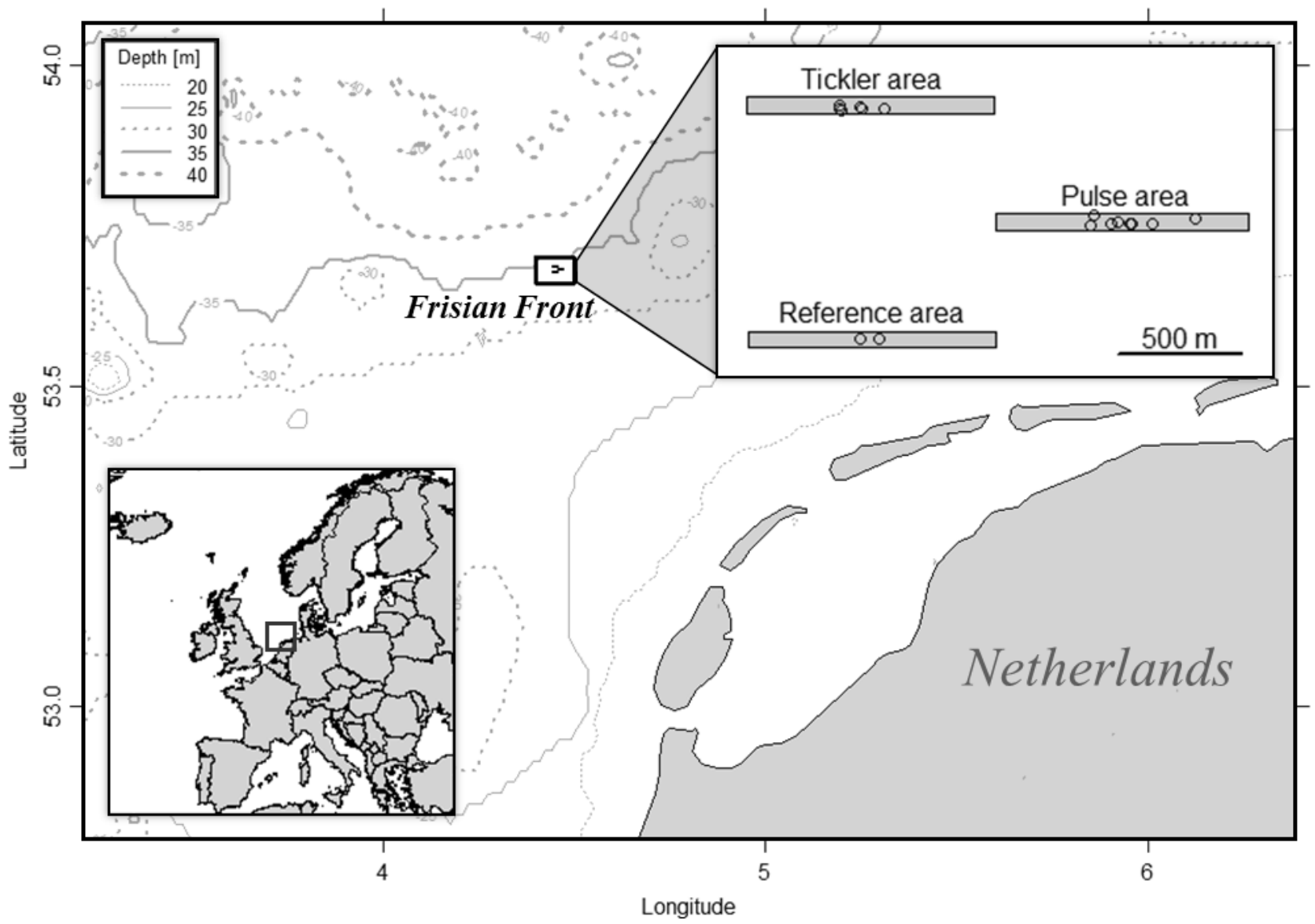

723 Figure 1. Map of the study site. The inset shows the positions of the experimental areas and box cores

724 taken from the tickler treatment to the north, the pulse treatment to the east and the reference area in the south. 


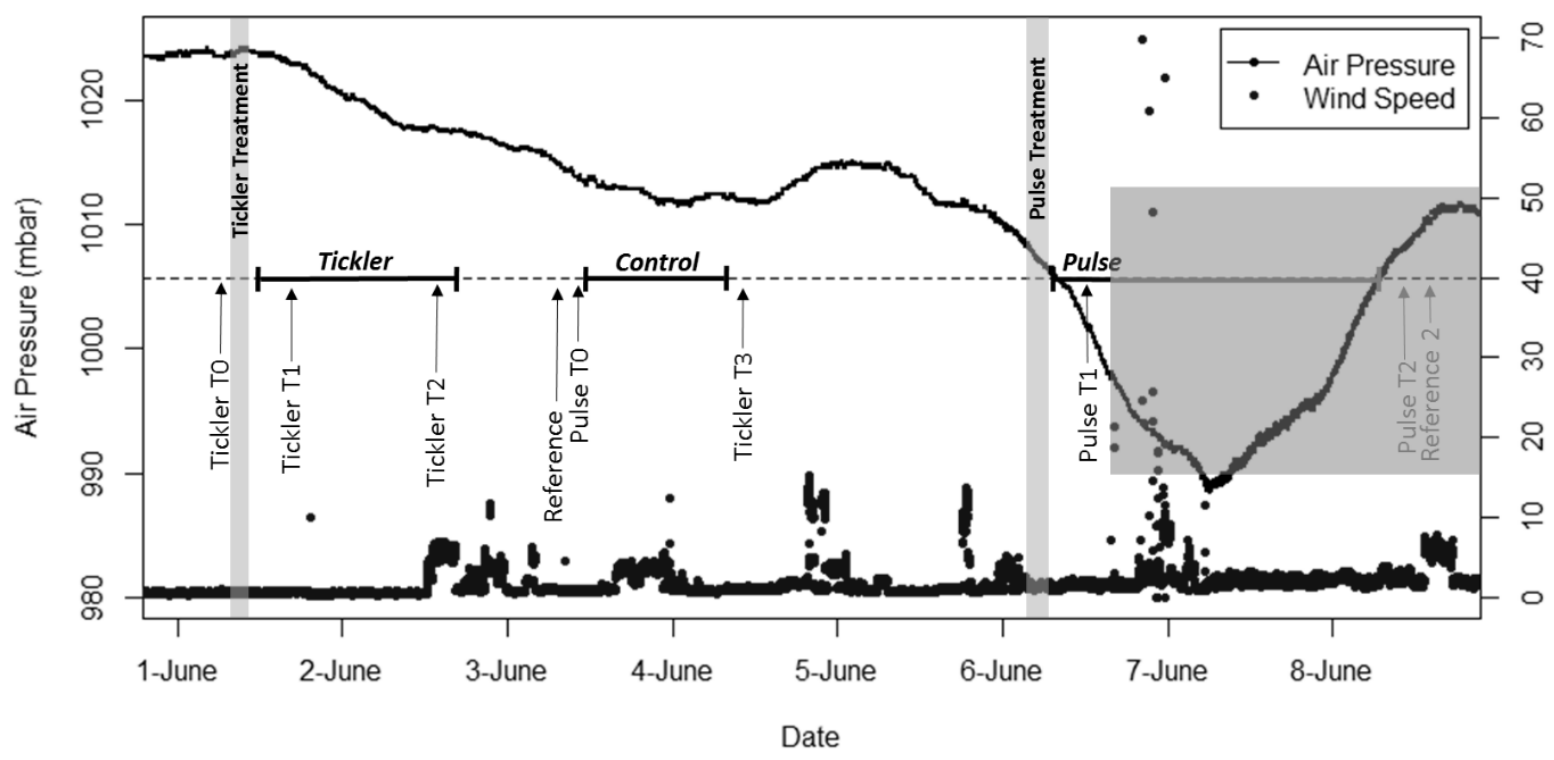

728 Figure 2. Sequence of events and weather conditions. Box core sediment samples (arrows), in-situ

729 lander deployments (brackets) and experimental fishing treatments (shaded columns) are shown.

730 Samples taken in the shaded region on the right were not included in the analysis due to storm 731 induced sediment disturbance. 
(a)

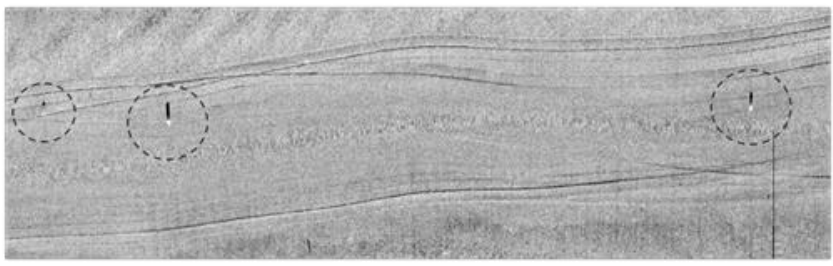

(b)

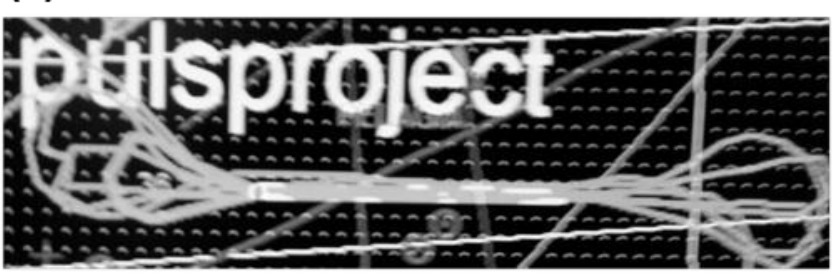

733 Figure 3. (a) A side-scan sonar image of the tickler trawled area. In addition to the evidence of

734 bottom disturbance, images of 2 benthic ALBEX landers and an additional oxygen sensing lander can

735 be seen within the disturbed portion of the seafloor. (b) Tracking of PulseWing trawl coordinates

736 showing the path taken by the fisherman while fishing the experimental (pulse) area. 
(a)

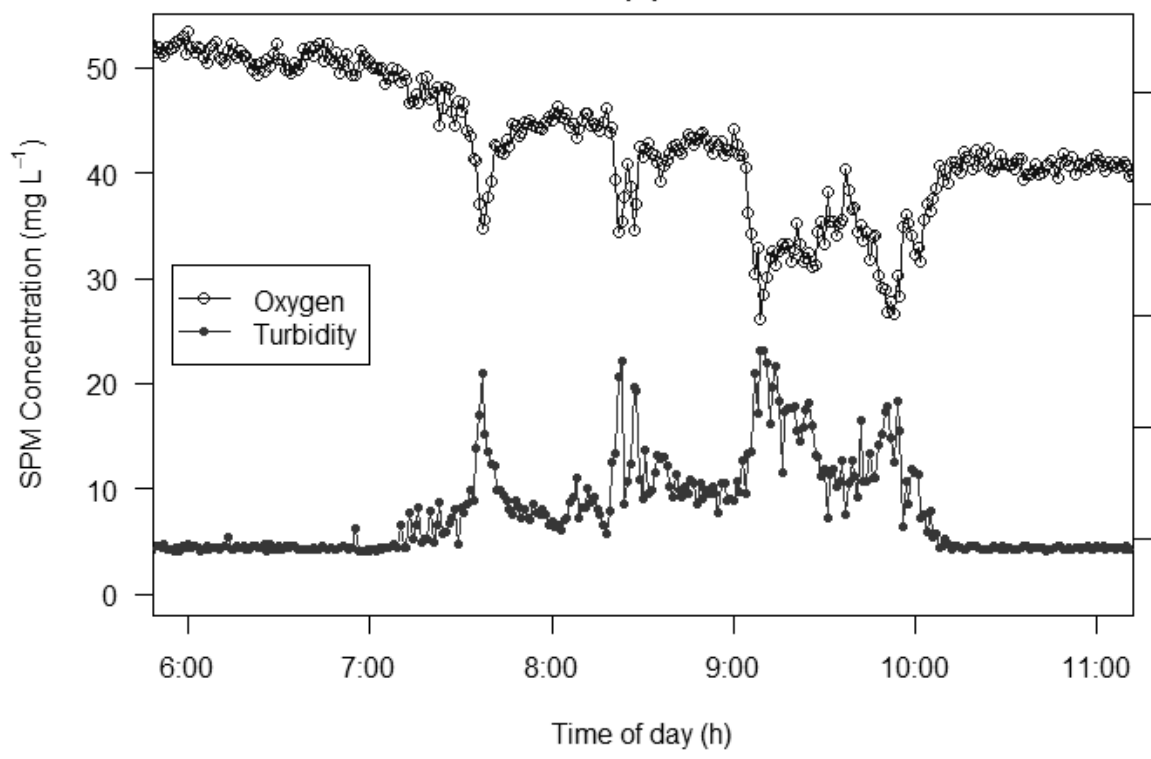

(b)

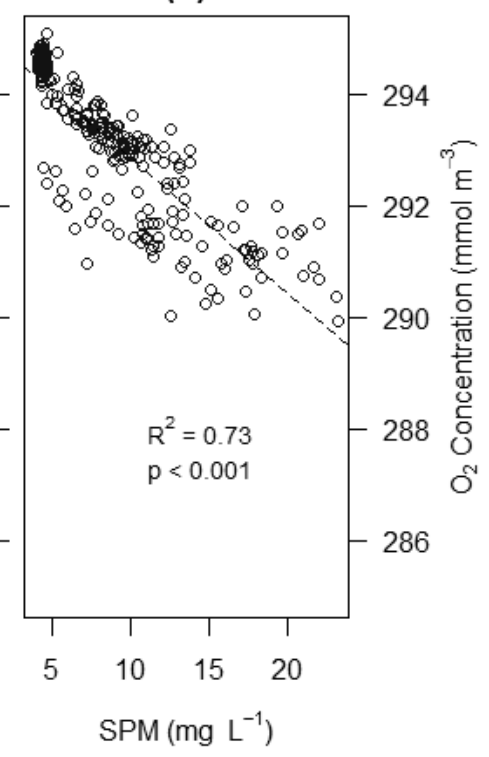

737

738 Figure 4. (a) PulseWing facilitated resuspension effects on SPM $\left(\mathrm{mg} \mathrm{L}^{-1}\right)$ and $\mathrm{O}_{2}\left(\mathrm{mmol} \mathrm{m}^{-3}\right)$

739 concentrations. Data was taken from $3.5 \mathrm{~m}$ above the sediment surface. (b) The relationship between

740 SPM (x-axis) and $\mathrm{O}_{2}$ concentration (y-axis) in the water column during pulse fishing. 


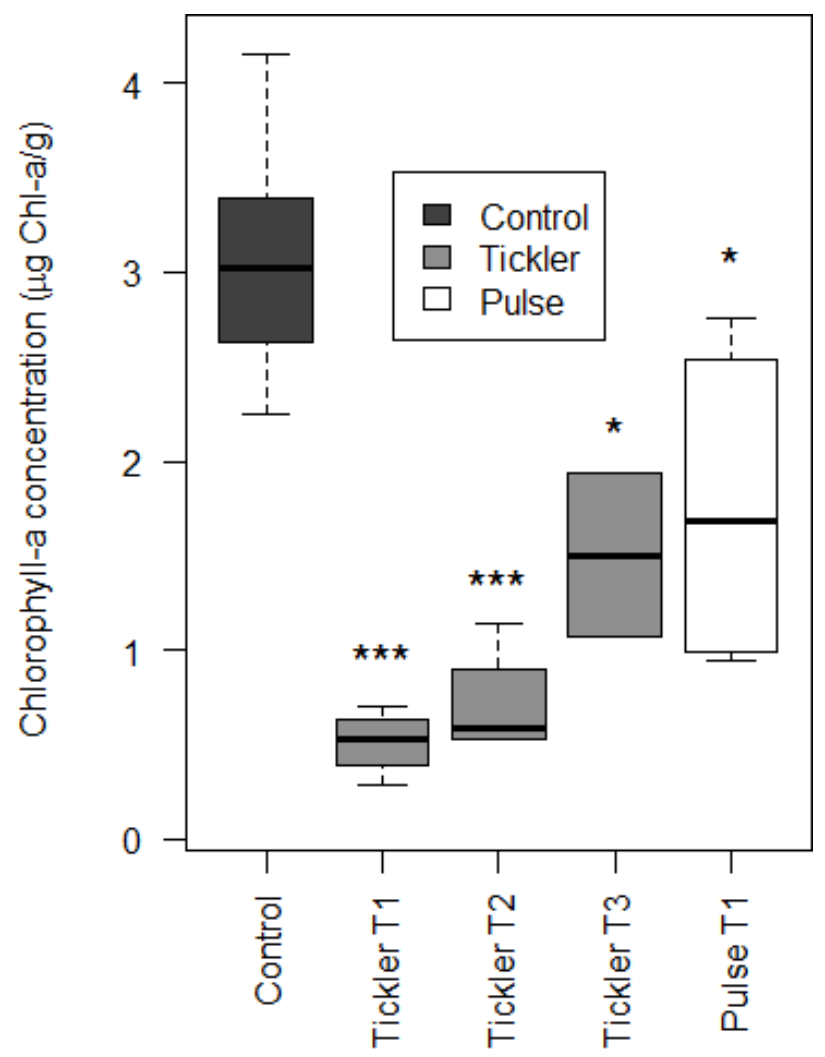

743 Figure 5. Surface chlorophyll- $a$ concentrations in control, tickler T1, tickler T2, tickler T3 and pulse

$744 \mathrm{~T} 1$ sediments. ${ }^{*} \mathrm{p}<0.05 ; * * \mathrm{p}<0.01 ; * * \mathrm{*} p<0.001$ significant differences compared to control 745 samples. 
Porewater ammonium concentration ( $\mu \mathrm{mol} / \mathrm{L}$ )
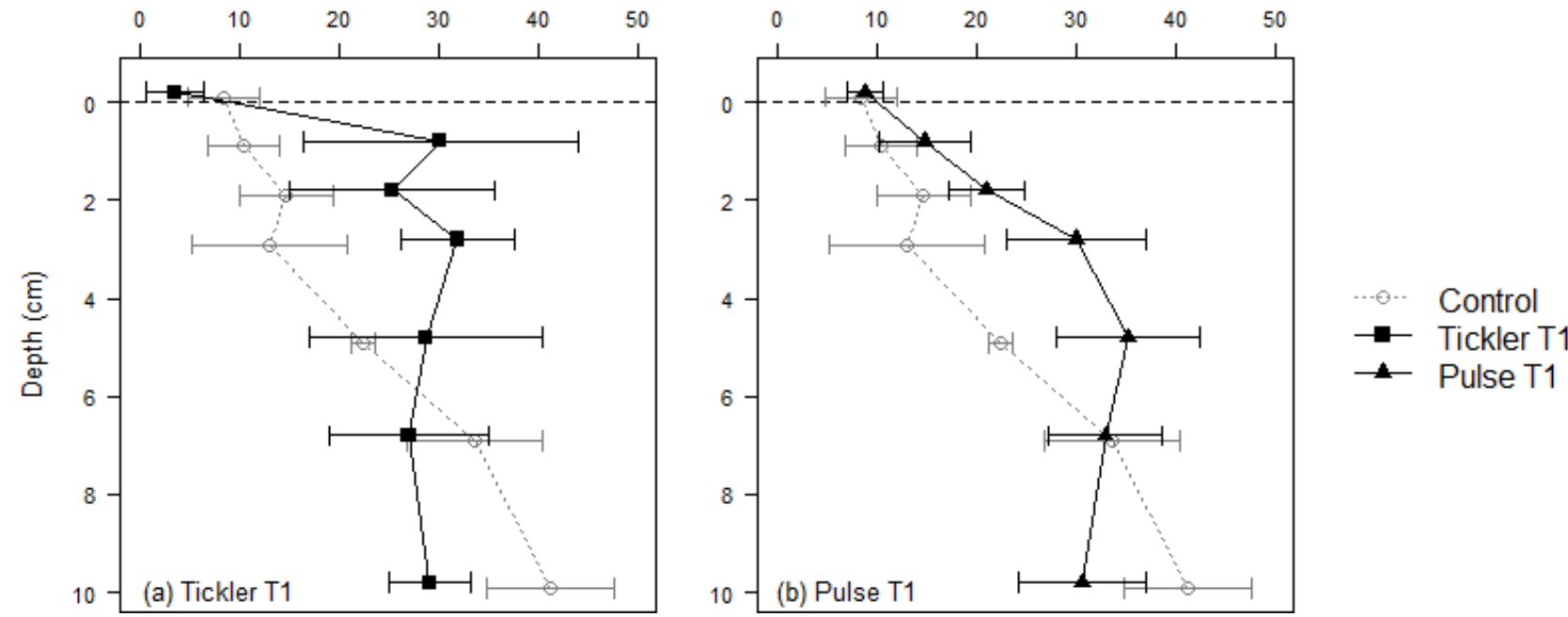

747 Figure 6. Porewater $\mathrm{NH}_{4}{ }^{+}$concentrations comparing (a) tickler $\mathrm{T} 1$ and (b) pulse $\mathrm{T} 1$ with control

748 (untrawled) samples 

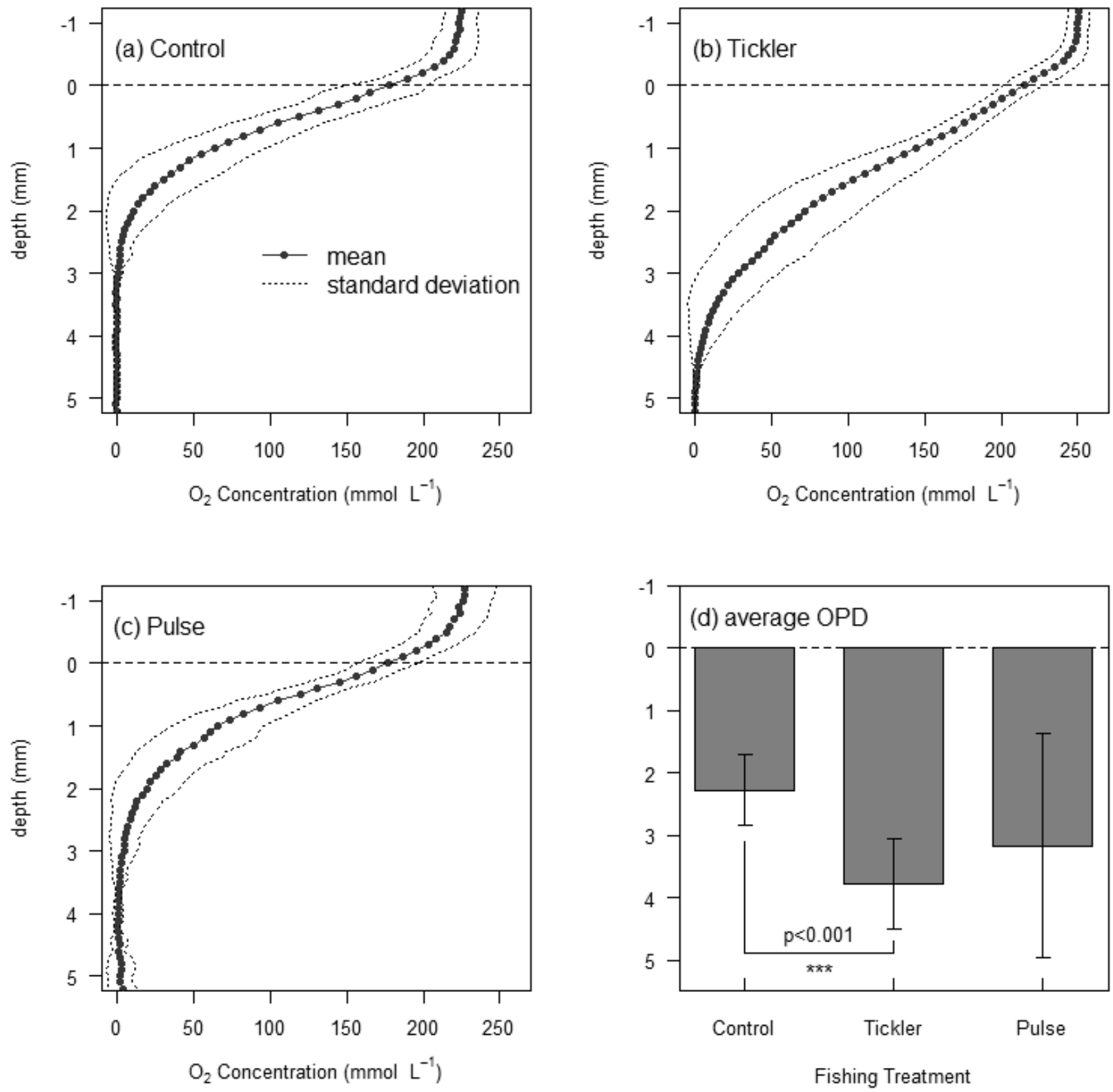

750 Figure 7. Oxygen microprofiles for (a) control, (b) tickler T1, and (c) pulse $\mathrm{T} 1$ areas. (d) Average $\mathrm{O}_{2}$

751 penetration depth $(\mathrm{mm})$ and standard deviation from each treatment. 

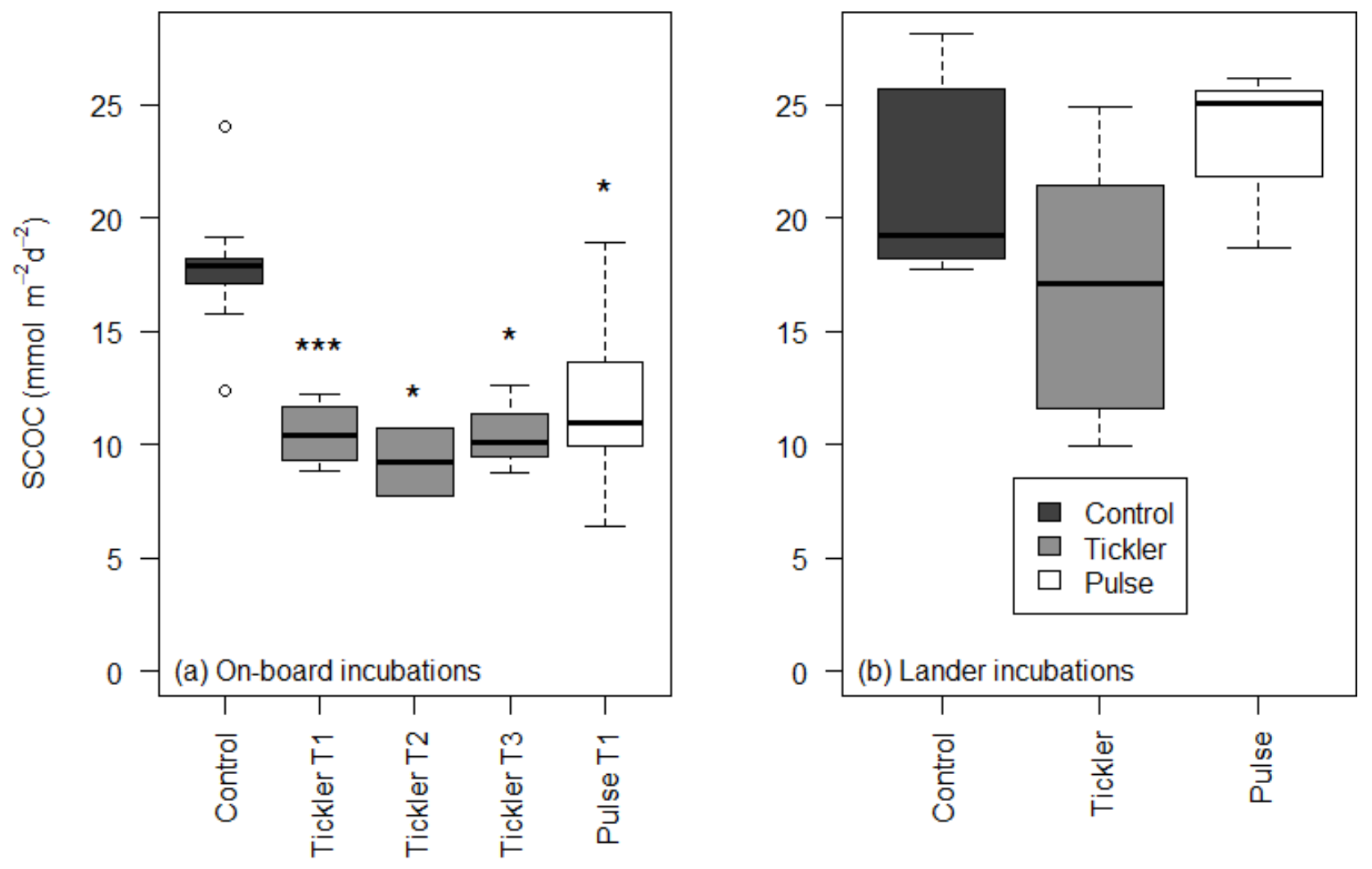

753 Figure 8. Sediment community oxygen consumption (SCOC) in control, tickler chain trawled and

754 PulseWing trawled sediments. (a) SCOC in on-board measurements taken from box core samples. (b)

$755 \mathrm{O}_{2}$ consumption measured from in-situ ALBEX landers. *p $<0.05 ; * * \mathrm{p}<0.01 ; * * * \mathrm{p}<0.001$

756 significant differences compared to control samples. 
Tables

Table 1. Grain size parameters taken from the top $2.5 \mathrm{~cm}$ : $\%$ silt $(<63 \mu \mathrm{m}), \%$ fine sand $(63$ $125 \mu \mathrm{m}), \mathrm{D50}=$ median grainsize $(\mu \mathrm{m}), \mathrm{D10}=$ diameter at which $10 \%$ of particles in the sample are smaller $(\mu \mathrm{m})$.

\begin{tabular}{cccccc}
\hline & $\begin{array}{c}\text { \% Silt } \\
\text { mean } \pm \text { sd }\end{array}$ & $\begin{array}{c}\text { \% Fine sand } \\
\text { mean } \pm \text { sd }\end{array}$ & $\begin{array}{c}\text { D50 } \\
\text { mean } \pm \text { sd }\end{array}$ & $\begin{array}{c}\text { D10 } \\
\text { mean } \pm \text { sd }\end{array}$ & $n$ \\
\hline Control & $33.06 \pm 7.33$ & $36.37 \pm 3.96$ & $91.81 \pm 11.95$ & $6.78 \pm 1.26$ & 9 \\
Tickler T1 & $26.17 \pm 2.74$ & $41.09 \pm 1.62$ & $99.46 \pm 3.22$ & $\mathbf{9 . 2 1} \pm \mathbf{1 . 2 1 *}$ & 4 \\
Tickler T2 & $\mathbf{2 0 . 4 6} \pm \mathbf{2 . 8 5 * * *}$ & $\mathbf{4 4 . 5 9} \pm \mathbf{2 . 4 8 *}$ & $105.22 \pm 2.63$ & $\mathbf{1 2 . 1 3} \pm \mathbf{1 . 4 2} * * *$ & 2 \\
Tickler T3 & $35.96 \pm 6.67$ & $34.94 \pm 2.47$ & $88.55 \pm 9.83$ & $6.14 \pm 1.53$ & 3 \\
Pulse T1 & $37.21 \pm 4.48$ & $33.53 \pm 2.26$ & $87.74 \pm 6.29$ & $5.58 \pm 1.03$ & 7 \\
\hline
\end{tabular}


Table 2. Percentage organic carbon and nitrogen content from the top $2.5 \mathrm{~cm}$

\begin{tabular}{cccc}
\hline & $\begin{array}{c}\text { \% OC } \\
\text { mean } \pm \mathrm{sd}\end{array}$ & $\begin{array}{c}\% \mathrm{TN} \\
\text { mean } \pm \mathrm{sd}\end{array}$ & $n$ \\
\hline Control & $0.35 \pm 0.09$ & $0.041 \pm 0.009$ & 9 \\
Tickler T1 & $0.30 \pm 0.04$ & $0.031 \pm 0.003$ & 4 \\
Tickler T2 & $0.24 \pm 0.04$ & $\mathbf{0 . 0 2 6} \pm \mathbf{0 . 0 0 2} * *$ & 2 \\
Tickler T3 & $0.37 \pm 0.15$ & $0.041 \pm 0.015$ & 3 \\
Pulse T1 & $0.43 \pm 0.04$ & $0.045 \pm 0.004$ & $\mathbf{7}$ \\
\hline
\end{tabular}

760

Bold = significantly different than control samples.

761 $* \mathrm{p}<0.05 ; * * \mathrm{p}<0.01 ; * * \mathrm{p}<0.001$ 
Table 3. Porewater nutrient concentrations in the upper $3 \mathrm{~cm}(\mu \mathrm{mol} / \mathrm{L})$

\begin{tabular}{cccccc}
\hline & $\begin{array}{c}\mathrm{NH}_{4}{ }^{+} \\
\text {mean } \pm \mathrm{sd}\end{array}$ & $\begin{array}{c}\mathrm{NO}_{\mathrm{x}} \\
\text { mean } \pm \mathrm{sd}\end{array}$ & $\begin{array}{c}\mathrm{PO}_{4}{ }^{3-} \\
\text { mean } \pm \mathrm{sd}\end{array}$ & $\begin{array}{c}\mathrm{SiO}_{2} \\
\text { mean } \pm \mathrm{sd}\end{array}$ & $n$ \\
\hline Control & $13.85 \pm 7.64$ & $2.94 \pm 5.64$ & $0.46 \pm 0.31$ & $85.48 \pm 19.16$ & 15 \\
Tickler T1 & $\mathbf{2 6 . 9 7} \pm \mathbf{9 . 2 7} * *$ & $2.52 \pm 1.85$ & $0.53 \pm 0.34$ & $80.00 \pm 23.46$ & 6 \\
Tickler T2 & $18.24 \pm 3.55$ & $2.55 \pm 1.60$ & $0.72 \pm 0.19$ & $69.40 \pm 14.63$ & 6 \\
Pulse T1 & $\mathbf{2 1 . 9 6} \pm \mathbf{8 . 1 0}$ & $1.58 \pm 0.42$ & $0.62 \pm 0.27$ & $80.53 \pm 12.78$ & 12 \\
\hline
\end{tabular}

763 Bold $=$ significantly different than control samples. ${ }^{*} \mathrm{p}<0.05 ; * * \mathrm{p}<0.01$ 
Table 4. Benthic oxygen and nutrient fluxes $\left(\mathrm{mmol} \mathrm{m}^{2} \mathrm{~d}^{-1)}\right.$ from on-board incubations and in-situ lander deployments. n.d. = no data, $\mathrm{O}_{2}$ "fluxes" are denoted as negative.

\begin{tabular}{|c|c|c|c|c|c|c|}
\hline $\begin{array}{l}\text { On-board } \\
\text { incubations }\end{array}$ & $\begin{array}{c}\mathrm{O}_{2} \\
\text { mean } \pm \mathrm{sd}\end{array}$ & $\begin{array}{c}\mathrm{NH}_{4}^{+} \\
\text {mean } \pm \mathrm{sd}\end{array}$ & $\begin{array}{c}\mathrm{NO}_{\mathrm{x}} \\
\text { mean } \pm \mathrm{sd}\end{array}$ & $\begin{array}{c}\mathrm{PO}_{4}{ }^{3-} \\
\text { mean } \pm \mathrm{sd}\end{array}$ & $\begin{array}{c}\mathrm{Si}(\mathrm{OH})_{4} \\
\text { mean } \pm \mathrm{sd}\end{array}$ & $n$ \\
\hline Control & $-17.78 \pm 3.07$ & $0.25 \pm 0.34$ & $0.106 \pm 0.03$ & $-0.003 \pm 0.02$ & $1.43 \pm 0.37$ & 9 \\
\hline Tickler T1 & $-10.46 \pm 1.50 * * *$ & $0.35 \pm 0.41$ & $0.095 \pm 0.02$ & $0.001 \pm 0.01$ & $1.10 \pm 0.41$ & 4 \\
\hline Tickler T2 & $-9.23 \pm 2.14 *$ & $0.10 \pm 0.13$ & $0.097 \pm 0.02$ & $0.001 \pm 0.01$ & $0.70 \pm 0.36$ & 2 \\
\hline Tickler T3 & $-10.51 \pm 1.96 *$ & n.d. & n.d. & n.d. & n.d. & 3 \\
\hline Pulse T1 & $-11.93 \pm 4.02 *$ & $0.28 \pm 0.25$ & $0.108 \pm 0.02$ & $0.002 \pm 0.01$ & $1.30 \pm 0.52$ & 7 \\
\hline $\begin{array}{l}\text { In-situ } \\
\text { incubations }\end{array}$ & $\begin{array}{c}\mathrm{O}_{2} \\
\text { mean } \pm \mathrm{sd}\end{array}$ & $\begin{array}{c}\mathrm{NH}_{4}^{+} \\
\text {mean } \pm \mathrm{sd}\end{array}$ & $\begin{array}{c}\mathrm{NO}_{\mathrm{x}} \\
\text { mean } \pm \mathrm{sd}\end{array}$ & $\begin{array}{c}\mathrm{PO}_{4}{ }^{3-} \\
\text { mean } \pm \mathrm{sd}\end{array}$ & $\begin{array}{c}\mathrm{Si}(\mathrm{OH})_{4} \\
\text { mean } \pm \mathrm{sd}\end{array}$ & $n$ \\
\hline Control & $-21.40 \pm 4.45$ & $0.39 \pm 0.29$ & $0.177 \pm 0.05$ & $0.071 \pm 0.03$ & $2.85 \pm 1.04$ & 6 \\
\hline Tickler & $-17.01 \pm 6.36$ & $0.61 \pm 0.55$ & $0.088 \pm 0.02 *$ & $0.076 \pm 0.04$ & $2.22 \pm 0.84$ & 6 \\
\hline Pulse & $-23.30 \pm 4.05$ & $0.17 \pm 0.12$ & $0.089 \pm 0.06$ & $0.047 \pm 0.02$ & $3.78 \pm 0.98$ & 3 \\
\hline
\end{tabular}

